the two experimental herds the onset rates in the controls between $D_{3}$ and $D_{5}$ were $4^{0.8}$ and 70.0 p. Ioo respectively.

59.2 p. roo of the sows farrowed after double insemination. There was no difference between the two doses of PMSG. The prolificacy was not significantly changed by the treatment.

This technique facilitates insemination of groups but the irregularity in the return to ostrus of certain sows may be a handicap.

\title{
INFLUENCE DE LA SURALIMENTATION DE LA TRUIE ET D'UNE INJECTION DE PMSG APRÈs SEVRAgE TRÈs PRÉCoce SUR L'OVULATION ET LA MORTALITÉ GMBRYONNAIRE
}

\author{
M. PAQUIGNON, J. RADISSON et F. du MESNIL du BUISSON \\ Station de Physiologie de la Reproduction, \\ Centre de Recherches de Tours, I. N.R.A., \\ Nouzilly 37380 Monnaie
}

\section{RÉSUMÉ}

Après une lactation de 5 à ro jours, 27 truies multipares Cotswold sont réparties en quatre lots. Les truies des lots A et B sont suralimentées, celles des lots $C$ et $D$ sous-alimentées entre le moment du sevrage et l'accouplement. Le lendemain du sevrage, les truies des lots A et D reçoivent une injection de I 200 UI de PMSG. Les truies saillies sont abattues $23( \pm \mathrm{I}$ ) jours après l'accouplement. 88 p. Ioo des truies sont en œstrus moins de i I jours après le sevrage. Un régime alimentaire élevé après le sevrage favorise significativement $(\mathrm{P}<\mathrm{o}$,or $)$ l'augmentation du nombre moyen de follicules kystiques par truie $(\mathrm{A}: 4,83 ; \mathrm{B}: 7,5 ; \mathrm{C}: 0 ; \mathrm{D} ; \mathrm{o})$. De même, le taux de mortalité embryonnaire est significativement plus élevé $(\mathrm{P} \pm 0, \mathrm{or})$ chez les truies supplémentées que chez les autres (A : 49,4 p. Ioo ; B : 66,6 p. Iоo ; C : 22,6 p. I00 ; D : 39,2 p. I00). L'utilisation de PMSG tend à augmenter le nombre de follicules formés et la survie embryonnaire. Dans tous les lots, nous avons constaté une répartition anarchique de l'implantation des embryons.

\section{SUMMARY}

\section{INFLUENCE OF OVER-FEEDING OF THF, SOW AND INJECTION OF PMSG AFTER EARLY WEANING ON OVULATION AND EMBRYONIC DEATH}

After a lactation period of 5-10 days, 27 multiparous Cotswold sows were divided into four groups. The sows of the groups $\mathrm{A}$ and $\mathrm{B}$ were over fed and those of the groups $\mathrm{C}$ and $\mathrm{D}$ under fed between weaning and mating. The day following weaning, the animals of groups $\mathrm{A}$ and $\mathrm{C}$ received an injection of $\mathrm{I} 200 \mathrm{IU}$ of PMSG. The sows were slaughtered 23 ( $\pm \mathrm{I}$ ) days after mating. 88 p. 100 of the sows returned to cstrus less than I I days after weaning. High diets offered after weaning significantly increased $(\mathrm{P}<\mathrm{o,oI})$ the mean number of cystic follicles 
$(\mathrm{A}: 4.83 ; \mathrm{B}: 7.5 ; \mathrm{C}: 0 ; \mathrm{D}: \mathrm{o})$. Fetal mortality rate was also significantly higher $(\mathrm{P}<\mathrm{o}, \mathrm{or})$ in the supplemented sows than in the others (A: 49.4 p. I00; B : 66.6 p. 100; C : 22.6 p. I0o ; $\mathrm{D}: 39.2$ p. I0o). Utilization of PMSG tend to increase the number of follicles developed and the embryonic survival. In all the groups an erratic distribution of embryo implantation was noticed.

\title{
DIAGNOSTIC DE GESTATION PAR BIOPSIE VAGINALE CHEZ LA TRUIE
}

\author{
J. GIRARDOT, M.-J. BOSC et F. BARITEAU \\ Station de Physiologie de la Nutrition, \\ Centre de Recherches de Tours, I. N.R. A., \\ Nouzilly 37380 Monnaie
}

\begin{abstract}
RÉSUMÉ
Le diagnostic de gestation par biopsic vaginale a été mis à l'essai chez la Truie. Dans une première expérience, la variation de l'épaisseur du nombre de couches cellulaires et de l'aspect qualitatif de l'épithélium vaginal ont été déterminées au cours du cycle œestrien, du I er mois de la gestation, de la lactation, et dans des cas de suspension anormale du cycle œstrien. Des critères de diagnostic de gestation en ont été clégagés; ils ont été éprouvés dans une deuxième expérience, sur 90 truies. L'exactitude du diagnostic de gestation a été égale à $86,3 \mathrm{p}$. Ioo pour les 22 biopsies prélevées $\mathrm{I} 8$ à 22 jours après IA, à $92, \mathrm{I}$ p. Ioo pour les 38 faites 23.27 jours après IA

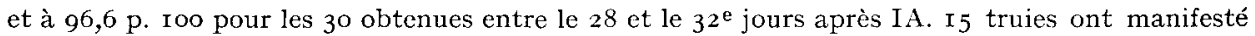
des retours en chaleurs anormaux et I I diagnostics exacts ont été portés. Ces résultats confirment ceux qui ont été obtenus par d'autres auteurs et ils soulignent l'intérêt de cette technique.
\end{abstract}

\section{SUMMARY}

\section{DIAGNOSIS OF PREGNANCY IN THE SOW BY VAGINAL BIOPSY}

Diagnosis of pregnancy by vaginal biopsy was investigated in the sow. During the first trial, variations in thickness, number of cellular layers and qualitative aspect of the vaginal epithelium were determined in the course of the estrus cycle, the first month of pregnancy, the first month of lactation and in the case of abnormal interruption of the estrus cycle. The diagnosis criteria obtained were tested in a second trial on go sows. The accuracy of the diagnosis of pregnancy was 86.3 p. Ioo for 22 biopsies collected i $8-22$ days afters AI, 92 . I p. Ioo for 38 biopsies collected 23-27 days after AI and 96.6 p. Ioo for 30 biopsies obtained between day 28 and 32 following AI. Fifteen sows exhibited abnormal return to heat and I I accurate diagnosis were made. These results confirm those obtained by other authors and emphasize the importance of this technique. 